\title{
Prophylactic cranial irradiation for patients with small-cell lung cancer: a systematic review of the literature with meta-analysis
}

\author{
Wenwen Zhang ${ }^{1}$, Wenjing Jiang ${ }^{1}$, Linlin Luan ${ }^{1}$, Lili Wang ${ }^{2}$, Xiangrong Zheng ${ }^{2}$ and Gongchao Wang ${ }^{1 *}$
}

\begin{abstract}
Background: Small cell lung cancer (SCLC) accounts for about 13\% of all lung cancer cases. Small cell lung cancer (SCLC) accounts for about 13\% of all lung cancer cases. The purpose of the present article is to assess the role of prophylactic cranial irradiation (PCI) in small cell lung cancer (SCLC) by performing a systematic review of the randomized trials published in the literature.

Methods: Randomized controlled trials were identified that compared brain metastases incidence and overall survival between $\mathrm{PCl}$ and $\mathrm{No} \mathrm{PCl}$ in patients with SCLC. Search strategies were limited to the English language and to articles published since 1997, and included: databases searched from 1997 to March 2013 -CINAHL, Embase, Medline, Web of Science, and CENTRAL. Methodological quality was assessed with the Jadad scale. The main end points were brain metastasis and survival.

Results: The review identified 5 trials, although few were of high quality. Two trials reported the one-year incidence of brain metastasis. $\mathrm{PCl}$ reduced the incidence of brain metastasis in one year, with a pooled relative risk of 0.45 ( $95 \% \mathrm{Cl}, 0.35$ to $0.58 ; \mathrm{P}<0.00001)$. Four trials described the one year survival rate. The combined result revealed a significant $(P=0.01)$ survival benefit in the group assigned to $\mathrm{PCl}$ as compared with the control group, with a pooled relative risk of $0.87(95 \% \mathrm{Cl}, 0.79$ to 0.97$)$. Three trials reported the three-year survival rate. The combined result revealed a great significant $(\mathrm{P}<0.00001)$ survival benefit in the $\mathrm{PCl}$ group as compared with the $\mathrm{No} \mathrm{PCl}$ group, with a pooled relative risk of $0.87(95 \% \mathrm{Cl}, 0.83$ to 0.91$)$. the Five-year survival rate was compared in four trials Compared with the No PCl group, the $\mathrm{PCl}$ group had a significant $(\mathrm{P}<0.00001)$ survival benefit with a pooled relative risk of $0.92(95 \% \mathrm{Cl}, 0.88$ to 0.95$)$.
\end{abstract}

Conclusions: The present systematic review indicates that $\mathrm{PCl}$ decreases brain metastases incidence and that PCl improves survival in SCLC patients. Prophylactic cranial irradiation should be part of standard care for all patients with small-cell lung cancer who have a response to initial chemotherapy, and it should be part of the standard treatment in future studies involving these patients.

Keywords: Prophylactic cranial irradiation, Small-cell lung cancer, Meta-analysis

\section{Background}

Small cell lung cancer (SCLC) accounts for about 13\% of all lung cancer cases [1]. SCLC is characterized by rapid doubling time, early dissemination and high sensitivity to chemotherapy and radiotherapy [2-4]. Chemotherapy has improved short-term survival, but long-term survival remains disappointing. The 2-year survival rate among

\footnotetext{
* Correspondence: wanggongchao@126.com

${ }^{1}$ School of Nursing, Shandong University, Jinan 250012, China

Full list of author information is available at the end of the article
}

patients with extensive small-cell lung cancer was 1.5\% in 1973 and $4.6 \%$ in 2000 [1]. SCLC has a propensity to metastasize to the brain. About $10 \%$ of the patients initially present with brain metastases. The two-year cumulative risk rises to $\geq 50 \%$ [5] and brain metastases are found in up to $65 \%$ of patients at autopsy [6]. The median survival time after brain metastases diagnosis is 4 to 5 months. Because the blood-brain barrier has been considered to protect the central nervous system (CNS) from

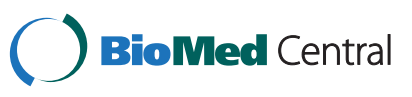

(c) 2014 Zhang et al.; licensee BioMed Central Ltd. This is an Open Access article distributed under the terms of the Creative Commons Attribution License (http://creativecommons.org/licenses/by/2.0), which permits unrestricted use, distribution, and reproduction in any medium, provided the original work is properly credited. The Creative Commons Public Domain Dedication waiver (http://creativecommons.org/publicdomain/zero/1.0/) applies to the data made available in this article, unless otherwise stated. 
most cytotoxic agents and as SCLC is very radiosensitive, the role of PCI has been studied in several trials [7].

PCI was first tested for patients with SCLC in the 1970s following the recognition that the blood-brain barrier appeared to restrict the penetration of most chemotherapeutics into the brain leaving it as a sanctuary site for relapse [8]. The first trial about PCI demonstrated substantial reductions in brain metastases [9]. The results of the randomized trials show that PCI reduces the frequency of brain metastases although survival is not consistently improved. Some data suggest that the gain in survival is restricted to patients in complete remission (CR). A published meta-analysis [9] of PCI for SCLC in patients with CR after chemotherapy has analyzed the data of 7 randomized studies (including one abstract and one unpublished study) concerning a total of 987 patients (526 treated with PCI and 461 controls). The relative risk (RR) of death in the treatment group as compared to the control group was 0.84 (95\% confidence interval CI: 0.73 to $0.97 ; p=0.01$ ). PCI decreased also the cumulative incidence of brain metastases (RR: 0.46; CI 95\%: 0.38-0.57; $p<0.001$ ). The results of these trials consistently revealed a significant decrease in the incidence of brain metastasis $[10,11]$. The purpose of the present article is to assess the role of PCI in SCLC by performing a systematic review of the randomized trials published in the literature.

\section{Methods}

\section{Trials selection}

Studies eligible for inclusion were randomized controlled clinical trials fully published in journals and those identified from other sources (abstracts and proceedings of relevant meetings) for which full details are available from investigators from 1997 to March 2013. Patients of any age had randomly assigned to receive PCI or not.

We searched CINAHL (from 1981), Embase (from 1980), Medline (from 1966), Web of Science (from 1966), and CENTRAL (from 1977) to present, using search strategies developed with the support of an information specialist that included exploded $\mathrm{MeSH}$ terms. Please see the Additional file 1.

Two independent reviewers read titles, abstracts, and full text papers and applied the inclusion criteria. Two reviewers independently extracted data from included full text papers. In case of incomplete or unclear data on study design and clinical outcome, authors were contacted. Discrepancies were resolved by a third referee.

\section{Methodological assessment}

Methodological quality of randomised controlled trials was assessed in accordance with a well-established, validated scale developed by Jadad and colleagues [12]. A Jadad score was calculated using 4 elements of consideration. 1) Was the randomization scheme described and appropriate? 2) Was the method of double-blinding appropriate? 3) Was the method of Concealment of allocation appropriate? 4) Was there a description of dropouts and withdrawals? The possible range of scores was from 0 (weakest) to 7 (strongest). Any study with a Jadad score below 3 was considered to be of poor quality.

Four authors independently evaluated the quality of the trials. Using a standardized protocol and reporting form, they extracted data on the subjects' characteristics at baseline and data on the clinical outcomes. Any disagreement was resolved through group discussion.

\section{Statistical analysis}

Statistical analysis was performed using the Review Manager 5.2. Relative risk (RR) and 95\% confidence intervals $(95 \% \mathrm{CI})$ were used as summary statistics. The pooled relative risk was calculated by using a fixed-effect model with the Mante-Haenszel method and the Breslow-Day test was used to examine the statistical evidence of heterogeneity across the studies $(p<0.1)$. The Der Simonian and Laird random effect model was additionally applied to calculate pooled relative risk in case of significant heterogeneity across studies.

Sensitivity analyses were performed to assess the effects of selected measures of study quality. The influence of each study was estimated by deleting each in turn

Table 1 Characteristics of the six trials included in the meta-analysis

\begin{tabular}{|c|c|c|c|c|c|c|}
\hline \multirow[t]{2}{*}{ Author } & \multirow[t]{2}{*}{ Year } & \multicolumn{2}{|c|}{ Age (Years) } & \multirow{2}{*}{$\begin{array}{c}\text { Median } \\
\text { follow-up (month) }\end{array}$} & \multirow{2}{*}{$\begin{array}{c}\text { Total dose/No. of } \\
\text { fraction (Dose/Fraction) }\end{array}$} & \multirow{2}{*}{$\begin{array}{l}\text { No. of } \\
\text { patient }\end{array}$} \\
\hline & & $\mathrm{PCl}$ & No PCI & & & \\
\hline \multirow[t]{2}{*}{ Gregor [11] } & 1997 & $60(37-79)$ & $61(28-76)$ & 18 & 36 Gy/18 (2 Gy) & 314 \\
\hline & & & & & 24 Gy/12 (2 Gy) & \\
\hline Laplanche [13] & 1998 & 58 & 57 & - & 24-30 Gy/8-10 & 211 \\
\hline Cao KJ [14] & 2005 & $54.69 \pm 7.56$ & $55.63 \pm 7.29$ & 60 & $36-40 \mathrm{~Gy} / 18-20$ & 51 \\
\hline Slotman [15] & 2007 & $63(37-75)$ & 63 (39-75) & 9 & 20-30 Gy/5-12 & 286 \\
\hline \multirow[t]{2}{*}{ Schild [8] } & 2012 & $63(34-79)$ & $63(37-80)$ & 72 & 30 Gy/15 (2 Gy) & 739 \\
\hline & & & & & 25 Gy/10 (2.5 Gy) & \\
\hline
\end{tabular}


Table 2 Jadad quality scores of the six trials included in the meta-analysis

\begin{tabular}{|c|c|c|c|c|c|}
\hline & Randomization & Concealment of allocation & Double blinding & Withdrawals and dropouts & Total \\
\hline Gregor 1997 [11] & 1 & 1 & 0 & 0 & 2 \\
\hline Laplanche 1998 [13] & 1 & 1 & 0 & 1 & 3 \\
\hline Cao KJ 2005 [14] & 1 & 1 & 0 & 0 & 2 \\
\hline Slotman 2007 [15] & 1 & 1 & 0 & 1 & 3 \\
\hline Schild 2012 [8] & 1 & 1 & 0 & 0 & 2 \\
\hline
\end{tabular}

from the analysis and noting the degree to which the effect size and significance of the treatment effect changed. This analysis was performed for each study outcome. We considered a study influential if the exclusion of it changed our conclusion or the effect estimate by at least $20 \%$.

\section{Results}

A total of 5 randomised trials published between 1997 and 2012 were found to be eligible for this review. This study includes two of the studies included on the Auperin metaanalysis (Gregor et al., Laplanche et al.) [9]. In addition, this meta-analysis also includes 3 newer studies that have been published well after the Auperin meta-analysis. Their main characteristics are summarized in Table 1 . The total number of eligible patients included was 1601; the number of patients by study ranged from 51 to 739 patients. The time of median follow-up ranged from 9 to 72 months.

\section{Methodological quality of included studies}

Initial agreement among reviewers on the overall methodological quality was $90 \%$, and after the consensus meeting, no disagreement persisted. The results of the methodological quality assessment are presented in Table 2 . All the studies were considered to be of low quality by scoring 2 or 3 .

\section{Brain metastasis}

Three trials reported the one-year incidence of brain metastasis. But we included two eligible trials. If Cao KJ's study was included, the heterogeneity would exist among the trials. So we excluded it. As shown in the
Figure 1, PCI reduced the incidence of brain metastasis in one year, with a pooled relative risk of 0.45 (95\% CI, 0.35 to $0.58 ; \mathrm{P}<0.00001)$.

\section{Overall survival}

One year survival rate were described in four trials between the PCI group and the No PCI group. We combined the result by using a fixed-effect model with the Mante-Haenszel method. The combined result showed that the heterogeneity existed among the trials (Figure 2). So we excluded two trials $[8,14]$. The combined result revealed a significant $(\mathrm{P}=0.01)$ survival benefit in the group assigned to PCI as compared with the control group, with a pooled relative risk of 0.87 (95\% CI, 0.79 to 0.97 ) (Figure 3).

Three trials with a total of 1104 patients reported the three-year survival rate. As depicted in Figure 4, the combined result revealed a great significant $(\mathrm{P}<0.00001)$ survival benefit in the PCI group as compared with the No PCI group, with a pooled relative risk of 0.87 (95\% CI, 0.83 to 0.91). As shown in Figure 5, the fiveyear survival rate was compared in four trials with a total of 1151 patients. Compared with the No PCI group, the PCI group had a significant $(\mathrm{P}<0.00001)$ survival benefit with a pooled relative risk of 0.92 (95\% CI, 0.88 to 0.95$)$.

\section{Discussion}

Our meta-analysis, by pooling five randomized studies that assessed PCI in 1941 patients with small-cell lung

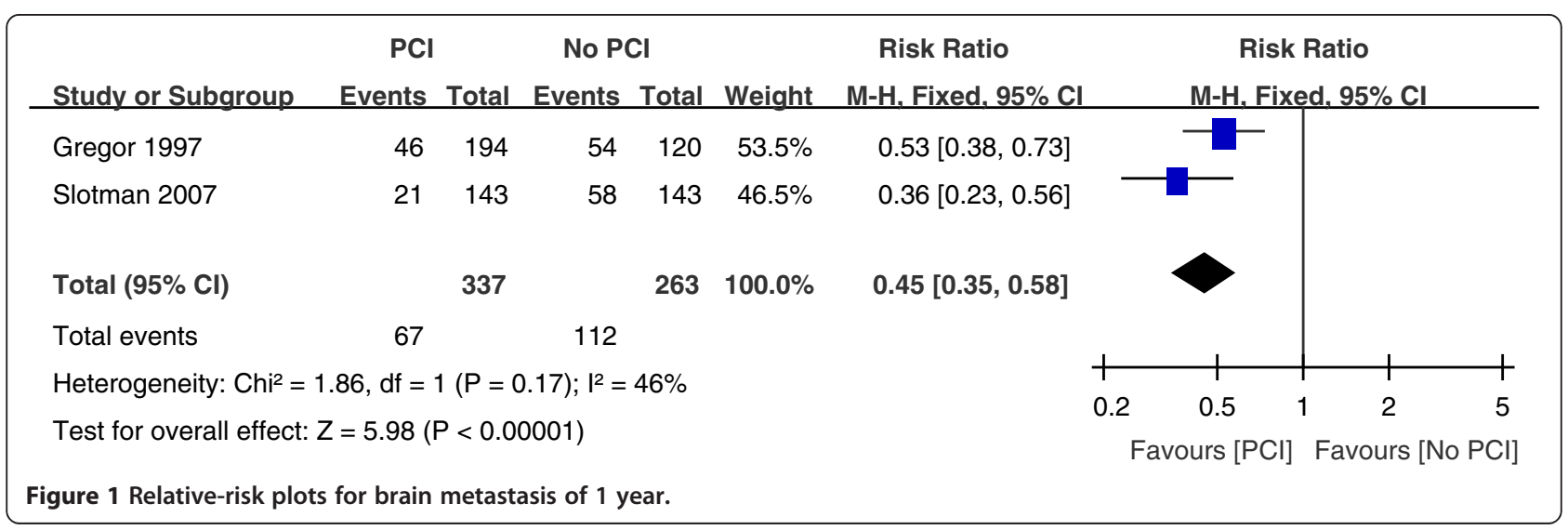




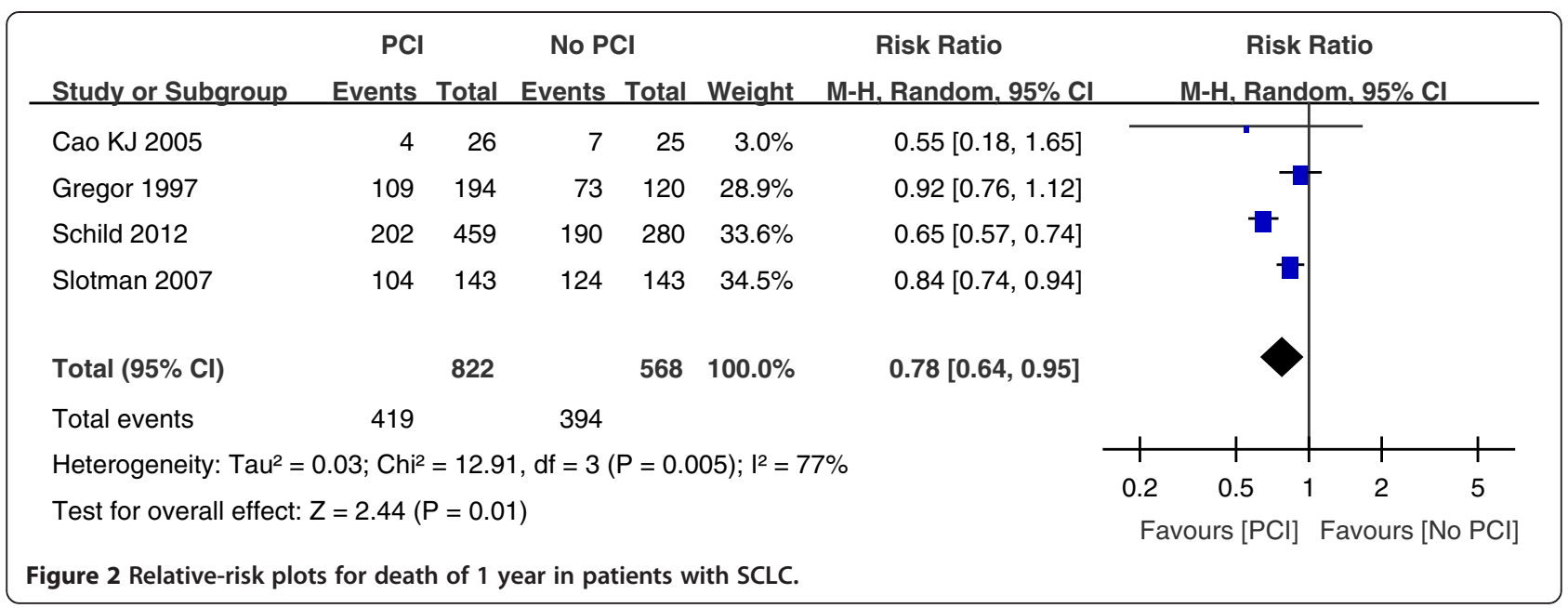

cancer, revealed a positive effect of PCI. As shown by the meta-analysis, irradiation not only significantly reduced the risk of brain metastasis, as previously revealed in individual trials, but also improved overall survival. These results confirm that PCI prevents and does not simply delay the emergence of brain metastases.

Brain metastasis is one of the most important causes of treatment failure in patients with SCLC. Most brain metastases occur within 2 years of diagnosis [16-22]. And median time to relapse in the brain is about 5.7 to 11.7 months [17-21]. Among the patients who survived for more than 2 years, about 50 percent of patients had brain metastasis [23]. With longer survival, brain metastases are being observed more often. PCI is effective in reducing the incidence of brain metastasis of SCLC. Several randomized studies showed that PCI reduced the rate of brain metastases in the patients with SCLC who achieved CR [10,24,25].Our meta-analysis also revealed that $\mathrm{PCI}$ reduced the incidence of brain metastasis within one year, with a pooled relative risk of 0.45 (95\% CI, 0.35 to $0.58 ; \mathrm{P}<0.00001)$. Combining with previous studies, we concluded that PCI reduced the incidence of brain metastases. Thus, patients with SCLC should be treated with PCI to reduce the incidence of brain metastasis.

In addition to thoracic radiotherapy, PCI has been shown to improve survival in SCLC patients. More recently, Patel et al. provided supporting data that PCI was associated with better survival of LSCLC patients [26]. This large retrospective analysis included 7995 patients with limited staged-SCLC. The 5-year survival was $11 \%$ without PCI versus $19 \%$ with PCI $(\mathrm{P}<0.001)$. PCI also improves survival rate for the majority of extensive staged-SCLC patients. Slotman et al. conducted a randomized trial of PCI in extensive staged-SCLC patients who had had any degree of response to chemotherapy [15]. Patients were randomly assigned to undergo PCI or the control group. The cumulative risk of brain metastases within 1 year was $14.6 \%$ in the PCI group and $40.4 \%$ in the control group ( $\mathrm{HR}, 0.27 ; \mathrm{P}<0.001)$. PCI was associated with an increase in median survival from 5.4 to 6.7 months after randomization. The 1 -year survival rate was doubled at $27.1 \%$ in the PCI group and $13.3 \%$ in the control group $(\mathrm{P}=0.003)$. Auperin et al. published a meta-analysis which included data from seven

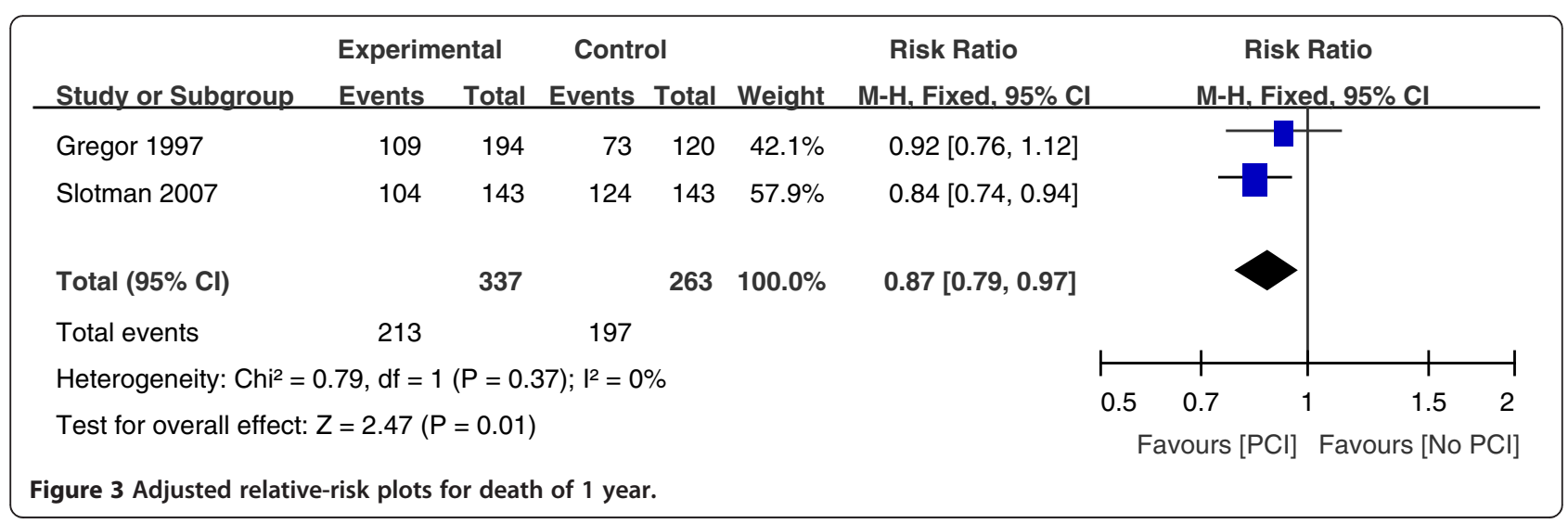




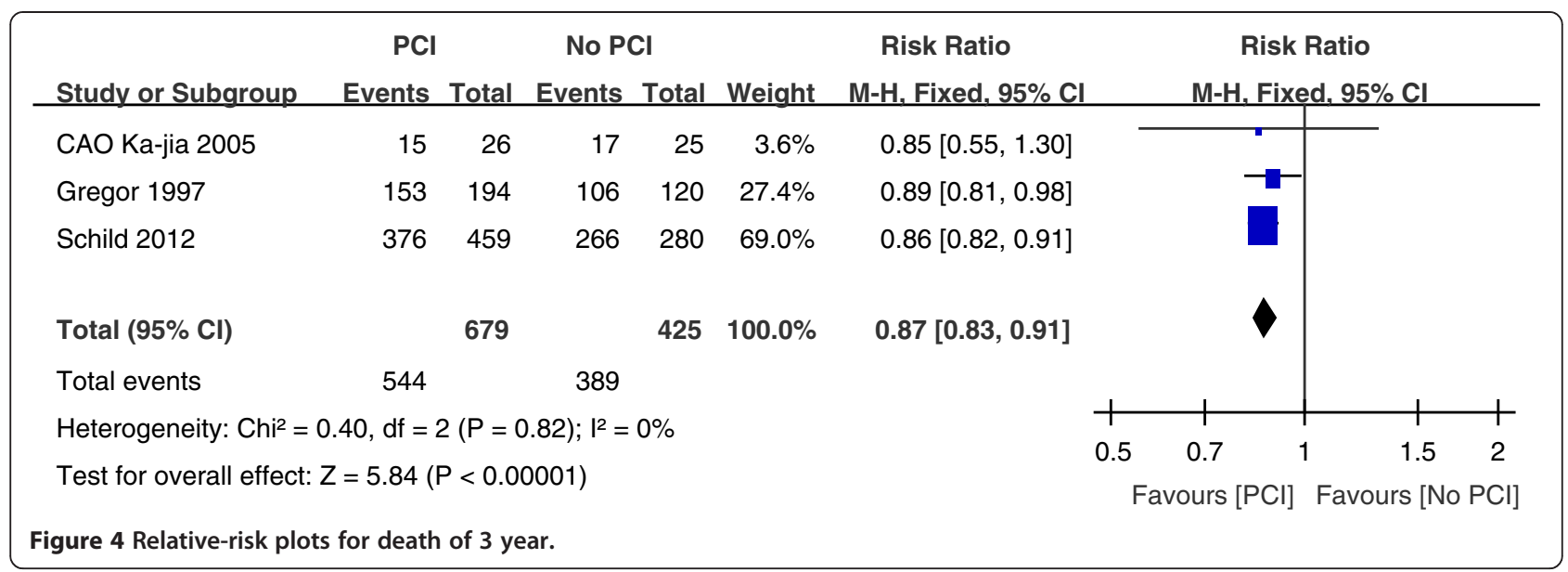

randomized prospective studies which compared PCI with no PCI after a CR was achieved [9]. The 3-year survival rate was $5.4 \%$ better for those who received PCI at $20.7 \%$ compared with $15.3 \%$ for those who did not receive $\mathrm{PCI}(\mathrm{P}=$ 0.01 ). While a $5.4 \%$ improvement in survival appears small, this reflects a $35 \%$ increase in 3-year survival and is clinically meaningful. According to our meta-analysis, the combined result for one-year survival rate revealed a significant $(\mathrm{P}=0.02)$ survival benefit in the group assigned to $\mathrm{PCI}$ as compared with the control group, with a pooled relative risk of 0.87 ( $95 \% \mathrm{CI}, 0.79$ to 0.97 ) (Figure 3). For the threeyear survival rate, the pooled relative risk was $0.87(95 \% \mathrm{CI}$, 0.83 to 0.91 ). And the pooled relative risk was 0.92 (95\% CI, 0.88 to 0.95 ) for five-year survival rate. The findings from the present analysis provide further support to the result that survival was significantly better for patients with SCLC who received PCI compared with No PCI.

There are some toxic events after the long-PCI. The most common acute toxic events were fatigue $30 \%$ of patients in the standard-dose group versus $34 \%$ in the higher dose group), nausea or vomiting (23\% versus
$28 \%$ ), and headache (24\% versus $28 \%$ ) [27]. Neurologic abnormalities seemed to be very common in long-term survivors with SCLC and may be more prominent in patients having received high-doses chemotherapy or treated with large brain radiotherapy fractions. In the 1980s, several nonrandomized studies found neuropsychological impairment and abnormalities on CT scans of the brain that were potentially related to PCI [28-32], and a recent study of patients treated by $\mathrm{PCI}$ and concomitant chemotherapy suggested that this combination had a negative effect on cognitive function, which was assessed at the end of treatment [33]. In this systematic review, we did not discuss the toxicities of long-term PCI. The problem of neuropsychological toxicity remains unclear, leading to controversy about the indications of PCI in SCLC. So further studies about neuropsychological toxicity of the long-term PCI need studied by the researchers in the future.

\section{Conclusions}

The present systematic review indicates that PCI decreases brain metastases incidence and that PCI improves

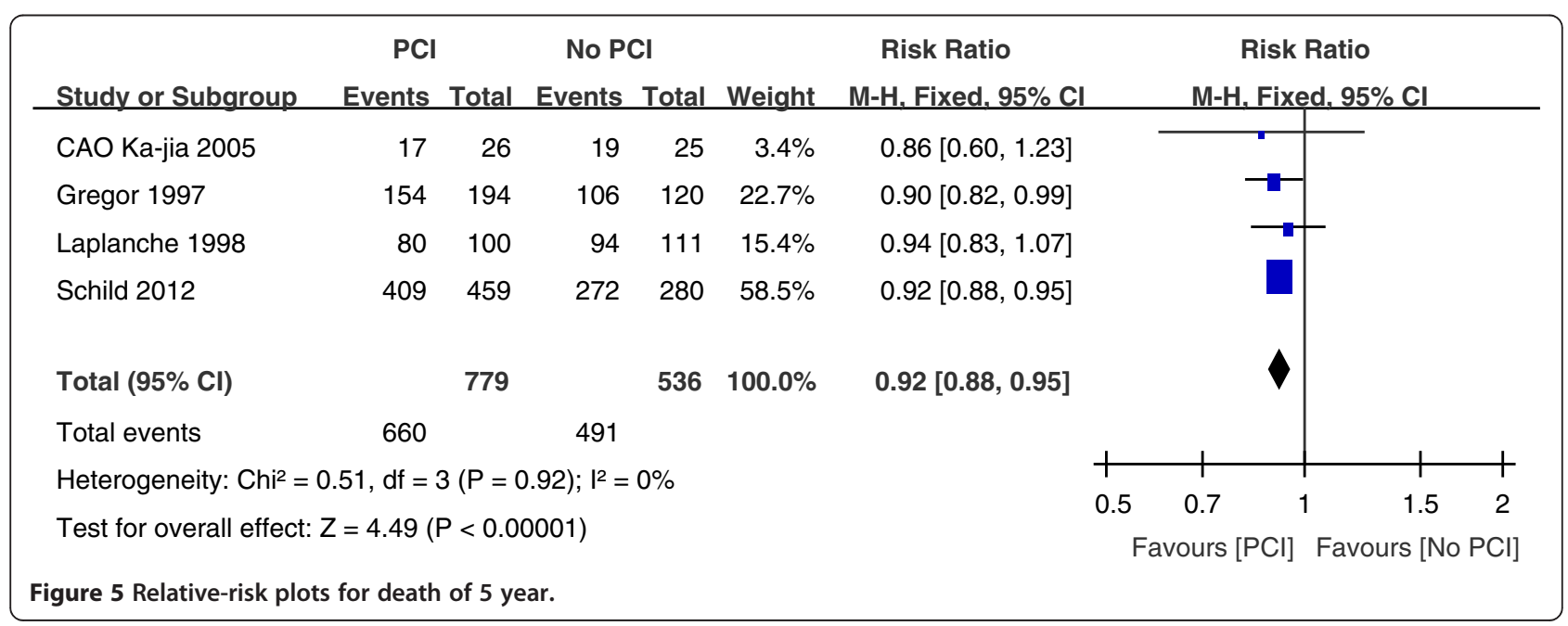


survival in SCLC patients. Prophylactic cranial irradiation should be part of standard care for all patients with smallcell lung cancer who have a response to initial chemotherapy, and it should be part of the standard treatment in future studies involving these patients.

\section{Additional file}

Additional file 1: PRISMA-Flow Diagram. It's a PRISMA flow diagram 278 for this study.

\section{Competing interests}

The authors declare that they have no competing interests.

\section{Authors' contributions}

ZWW, JWJ and WGC have made substantial contributions to design the study. ZWW, JWJ, LLL and ZXR have screened papers and conducted the quality rating and meta-analysis. The statistical analyses were conducted by ZWW, WLL and ZXR. ZWW, JWJ and LLL have been involved in drafting the manuscript. WGC, WLL and ZXR have been involved in critically revising the manuscript. All authors read and approved the final manuscript.

\section{Acknowledgements}

We greatly appreciate all the members of our group for their endeavor. And we are very grateful to Wang Gongchao for carefully reading and correcting the manuscript text.

\section{Author details}

${ }^{1}$ School of Nursing, Shandong University, Jinan 250012, China. ${ }^{2}$ School of Medicine, Shandong University, Jinan 250012, China.

Received: 8 April 2013 Accepted: 17 October 2014

Published: 31 October 2014

\section{References}

1. Govindan R, Page N, Morgensztern D, Read W, Tierney R, Vlahiotis A, Spitznagel EL, Piccirillo J: Changing epidemiology of small-cell lung cancer in the United States over the last 30 years: analysis of the Surveillance, Epidemiologic, and End Results database. J Clin Oncol 2006, 24:4539-4544.

2. Brade AM, Tannock IF: Scheduling of radiation and chemotherapy for limited-stage small-cell lung cancer: Repopulation as a cause of treatment failure? J Clin Oncol 2006, 24:1020-1022.

3. Jackman DM, Johnson B: Small-cell lung cancer. Lancet 2005, 366:1385-1396.

4. Stupp R, Monnerat C, Turrisi AT: Small cell lung cancer: state of the art and future perspectives. Lung Cancer 2004, 45:105-117.

5. Komaki R, Cox JD, Whitson W: Risk of brain metastases from small-cell carcinoma of the lung related to the length of survival and prophylactic irradiation. Cancer Treat Rep 1981, 65:811-814.

6. Nugent JL, Bunn PA, Matthews MJ, Ihde DC, Cohen MH, Gazdar A, Minna JD: CNS metastases in small cell bronchogenic carcinoma. Cancer 1979, 44:1885-1893

7. Meert AP, Paesmans M, Berghmans T, Martin B, Mascaux C, Vallot F, Verdebout JM, Lafitte JJ, Sculier JP: Prophylactic cranial irradiation in small cell lung cancer: a systematic review of the literature with meta-analysis. BMC Cancer 2001, 1:5.

8. Schild SE, Foster NR, Meyers JP, Ross HJ, Stella PJ, Garces YI, Olivier KR Molina JR, Past LR, Adjei AA: Prophylactic cranial irradiation in small-cell lung cancer: Findings from a North Central Cancer Treatment Group Pooled Analysis. Ann Oncol 2012, 23:2919-2924.

9. Aupérin A, Arriagada R, Pignon JP, Le Péchoux C, Gregor A, Stephens RJ, Kristiansen PE, Johnson BE, Ueoka H, Wagner H, Aisner J: Prophylactic cranial irradiation for patients with small-cell lung cancer in complete remission. Prophylactic Cranial Irradiation Overview Collaborative Group. N Engl J Med 1999, 341:476-484.

10. Arriagada R, Le Chevalier T, Borie F, Rivière A, Chomy P, Monnet I, Tardivon A, Viader F, Tarayre M, Benhamou S: Prophylactic cranial irradiation for patients with small-cell lung cancer in complete remission. J Natl Cancer Inst 1995, 87:183-290.
11. Gregor A, Cull A, Stephens RJ, Kirkpatrick JA, Yarnold JR, Girling DJ, Macbeth FR, Stout R, Machin D: Prophylactic cranial irradiation is indicated following complete response to induction therapy in small cell lung cancer: results of a multicentre randomised trial. Eur J Cancer 1997, 33:1752-1758.

12. Jadad AR, Moore RA, Carroll D, Jenkinson C, Reynolds DJ, Ciavaghan DJ, McQJuay HJ: Assessing the quality of reports of randomized clinical trials: is blinding necessary? Clontrol Clin Trials 1996, 17(1):1-12.

13. Laplanche A, Monnet I, Santos-Miranda JA, Bardet E, Le Péchoux C, Tarayre $M$, Arriagada R: Controlled clinical trial of prophylactic cranial irradiation for patients with small-cell lung cancer in complete remission. Lung Cancer 1998, 21:193-201.

14. Cao KJ, Huang HY, Tu MC, Pan GY: Long-term results of prophylactic cranial irradiation for limited-staged small-cell lung cancer in complete remission. Chin Med J 2005, 118(15):1258-1262.

15. Slotman B, Faivre-Finn C, Kramer G, Rankin E, Snee M, Hatton M, Postmus P, Collette L, Musat E, Senan S: Prophylactic Cranial Irradiation in Extensive Small-Cell Lung Cancer. N Engl J Med 2007, 357(7):664-672.

16. Law A, Karp DD, Dipetrillo T, Daly BT: Emergence of increased cerebral metastasis after preoperative radiotherapy with chemotherapy in patients with locally advanced non-small-cell lung carcinoma. Cancer 2001, 92:160-164.

17. Komaki R, Scott CB, Byhardt R, Emami B, Asbell SO, Russell AH, Roach M, Parliament MB, Gaspar LE: Failure patterns by prognostic group determined by recursive partitioning analysis (RPA) of 1547 patients on four Radiation Therapy Oncology Group (RTOG) studies in inoperable non-small-cell lung cancer. Int J Radiat Oncol Biol Phys 1998, 42:263-267.

18. Carolan H, Sun AY, Bezjak A, Yi QL, Payne D, Kane G, Waldron J, Leighl N, Feld R, Burkes R, Keshavjee S, Shepherd F: Does the incidence and outcome of brain metastases in locally advanced non-small-cell lung cancer justify prophylactic cranial irradiation or early detection? Lung Cancer 2005, 49:109-115

19. Chen AM, Jahan TM, Jablons DM, Garcia J, Larson DA: Risk of cerebral metastases and neurological death after pathological complete response to neoadjuvant therapy for locally advanced non-small-cell lung cancer: Clinical implications for the subsequent management of the brain. Cancer 2007, 109:1668-1675.

20. Ceresoli GL, Reni M, Chiesa G, Carretta A, Schipani S, Passoni P, Bolognesi A, Zannini P, Villa E: Brain metastases in locally advanced non-small-cell lung carcinoma after multimodality treatment: Risk factors analysis. Cancer 2002, 95:605-612

21. Robnett TJ, Machtay M, Stevenson JP, Algazy KM, Hahn SM: Factors affecting the risk of brain metastases after definitive chemoradiation for locally advanced non-small-cell lung carcinoma. J Clin Oncol 2011, 9:1344-1349.

22. Gaspar LE, Chansky K, Albain KS, Vallieres E, Rusch V, Crowley JJ, Livingston RB, Gandara DR: Time from treatment to subsequent diagnosis of brain metastases in stage III non-small cell lung cancer: A retrospective review by the Southwest Oncology Group. J Clin Oncol 2005, 23:2955-2961.

23. Arriagada R, Le Chevalier T, Rivière A, Chomy P, Monnet I, Bardet E, SantosMiranda JA, Le Péhoux C, Tarayre M, Benhamou S, Laplanche A: Patterns of failure after prophylactic cranial irradiation in small-cell lung cancer: analysis of 505 randomized patients. Ann Oncol 2002, 13:748-754.

24. Alexopoulos CG, Vaslamltzis M, Patila E, Taranto L: Central nervous system involvement and the role of prophylactic cranial irradiation in small-cell lung cancer. Oncologist 1979, 2:153-159.

25. Ohonoshi T, Ueoka H, Kawahara S, Ohonoshi T, Ueoka H, Kawahara S, Kiura K, Kamei H, Hiraki Y, Segawa Y, Hiraki S, Kimura I: Comparative study of prophylactic cranial irradiation in patients with small-cell lung cancer achieving a complete response: a long-term follow-up result. Lung Cancer 1993, 10:47-54

26. Patel S, Macdonald OK, Suntharalingam M: Evaluation of the use of prophylactic cranial irradiation in small cell lung cancer. Cancer 2009, 115:842-850.

27. Wolfson AH, Bae K, Komaki R, Meyers C, Movsas B, Le Pechoux C, WernerWasik M, Videtic GM, Garces YI, Choy H: Primary Analysis of a Phase II Randomized Trial Radiation Therapy Oncology Group (RTOG) 0212: impact of different total doses and schedules of prophylactic cranial irradiation on chronic neurotoxicity and quality of life for patients with limited-disease small-cell lung cancer. Int I Radiat Oncol Biol Phys 2011, 81:77-84.

28. Catane R, Schwade JG, Yarr I, Lichter AS, Tepper JE, Dunnick NR, Brody L, Brereton HD, Cohen M, Glatstein E: Follow-up and neurological evaluation 
in patients with small cell lung carcinoma treated with prophylactic cranial irradiation and chemotherapy. Int J Radiat Oncol Biol Phys 1981, 7:105-109.

29. Johnson BE, Patronas N, Hayes W, Grayson J, Becker B, Gnepp D, Rowland J, Anderson A, Glatstein E, Ihde DC: Neurologic, computed cranial tomographic, and magnetic resonance imaging abnormalities in patients with small-cell lung cancer: further follow-up of 6- to 13-year survivors. J Clin Oncol 1990, 8:48-56.

30. Lee JS, Umsawasdi T, Lee YY, Barkley HT Jr, Murphy WK, Welch S, Valdivieso M: Neurotoxicity in long-term survivors of small cell lung cancer. Int $J$ Radiat Oncol Biol Phys 1986, 12:313-321.

31. Lishner M, Feld R, Payne DG, Sagman U, Sculier JP, Pringle JF, Yeoh JL, Evans WK, Shepherd FA, Maki E: Late neurological complications after prophylactic cranial irradiation in patients with small-cell lung cancer: the Toronto experience. J Clin Oncol 1990, 8:215-221.

32. Frytak S, Shaw JN, O'Neill BP, Lee RE, Eagan RT, Shaw EG, Richardson RL, Coles DT, Jett JR: Leukoencephalopathy in small cell lung cancer patients receiving prophylactic cranial irradiation. Am J Clin Oncol 1989, 12:27-33.

33. Ahles TA, Silberfarb PM, Herndon $J \|$, Maurer $L H$, Kornblith AB, Aisner J, Perry MC, Eaton WL, Zacharski LL, Green MR, Holland JC: Psychologic and neu-ropsychologic functioning of patients with limited small-cell lung cancer treated with chemotherapy and radiation therapy with or without warfarin: a study by the Cancer and Leukemia Group B. J Clin Oncol 1998, 16:1954-1960.

doi:10.1186/1471-2407-14-793

Cite this article as: Zhang et al:: Prophylactic cranial irradiation for patients with small-cell lung cancer: a systematic review of the literature with meta-analysis. BMC Cancer 2014 14:793.

\section{Submit your next manuscript to BioMed Central and take full advantage of:}

- Convenient online submission

- Thorough peer review

- No space constraints or color figure charges

- Immediate publication on acceptance

- Inclusion in PubMed, CAS, Scopus and Google Scholar

- Research which is freely available for redistribution

Submit your manuscript at www.biomedcentral.com/submit
C Biomed Central 